\title{
Building capacity for their members: What employers' organisations in South Africa need to know
}

\author{
P.A. Grobler*, M. Kirsten and S Wärnich \\ Department of Business Management, University of South Africa, \\ PO Box 392, Pretoria 0003, Republic of South Africa \\ groblpa@unisa.ac.za
}

Received December 2004

\begin{abstract}
According to Chapter 2 of the Labour Relations Act 66 of 1995, employers, like trade unions, have a right to freedom of association. However, hardly any research has been conducted to establish the efficiency/effectiveness of employers' organisations. The question thus is: To what extent do members (companies) make use of the services rendered by their employers' organisations, and how satisfied are they with the service provided? From this study it is clear that a small percentage of companies avail themselves of the services of employers' organisations. Popular areas of contact appear to be human resource management, labour relations and training. A number of problems in the area of client satisfaction have been identified and recommendations are made to increase the efficiency/effectiveness of employers' organisations. It is clear that despite the limited use of their services, employers' organisations continue to fulfil a key role in the labour dispensation in South Africa.
\end{abstract}

*To whom all correspondence should be addressed.

\section{Introduction}

The Labour Relations Act 66 of 1995 (Chapter 2, ss 6 \& 7) grants both employers and trade unions similar rights relating to freedom of association. For example, every employer has the right to form, join or participate in the lawful activities of an employers' organisation. This right is protected by a general provision in terms of which nobody may discriminate against an employer for exercising any right in terms of the Act. The process for registration of employers' organisations is essentially the same as that for trade unions.

According to Venter (2003:86), South African employer groups have traditionally been relatively weak, compared with their union counterparts. This is possibly because government policy under apartheid favoured business by subordinating labour for so long that employers did not need a strong, coordinated response to counter the effect of a strong labour movement. However, Finnemore and Van Rensburg (2002:182) contend that the role of employers' organisations in South Africa has gained greater significance in recent years for several reasons. The pressure from trade unions for centralised negotiations, initially on industrial councils, and now on bargaining councils, required an organised employer response. Unions have also grown and grouped into strong national federations with significant sociopolitical influence. This propelled the development of a strong counterforce among employers, especially because negotiations of critical national issues in various forums, have proceeded. In addition, with South Africa's re-entry into the international arena, the need for an organisation to represent employers' interest at the International Labour
Organisation (ILO), gave further impetus to moves for a single national body which could speak and act for all employers. At present, some 259 employers' organisations and approximately 345 trade unions are registered with the Department of Labour.

However, little research has been undertaken in the area of employer organisation efficiency/ effectiveness. On the basis of this, the International Labour Organisation launched a study of 18 countries including South Africa. The primary objective of this study was, firstly, to establish to what extent members (companies) avail themselves of the services of their employers' organisations, and secondly, to what extent they were satisfied with the service they receive from these organisations. The aim of this paper is thus to present the findings of the South African leg of the study. The paper is structured as follows: the next section will present a brief historical overview of the literature on employers' organisations, followed by a description of the methodology used in the research. Next, the results of the research will be presented, and finally, a number of recommendations are made.

\section{Literature review}

Employers' organisations generally owe their existence to attempts mainly initiated by the employers themselves, and only rarely by outsiders, in order to pursue their collective interests (Beardwell \& Holden, 1997:522). They organise to achieve one or several aims namely: to regulate matters of trade and competition by mutual agreement; to seek statutory protection in matters of trade, particularly with regard to imported goods; to establish a united front in 
dealing with trade unions; to provide services in labour relations and human resource management; and to contest the passage of social and labour legislation (Windmuller \& Gladstone, 1984:1).

While the chief organisational impetus was commercial interests, the outcome was the formation of what is generally referred to as a 'trade association'. By contrast, where the issues centred on the employment relationship, the desire for joint action led to the formation of 'employers' associations' (Windmuller \& Gladstone, 1984:1). Despite this distinction, it is important to note that there are many instances where a single association serves both trade and labour policy objectives (Dessler, 2000:630).

To distinguish trade associations, with their essentially economic policy functions, from employers' associations, with their basically social and labour policy concerns, the terms 'economic' and 'social' became standard parts of the language in most European countries (Windmuller \& Gladstone, 1984:2). According to Windmuller and Gladstone (1984:2), 'economic' associations saw to matters of trade regulation, tax policy, product standardisation, cartel arrangements and similar issues, while the so-called 'social' associations, took responsibility for all aspects of the employment relationship, including relations with unions, human resource management policies, and the legislative, administrative and adjudicatory role of the state and its agencies in labour matters. It is interesting to note that by the mid-nineteenth century, a number of national employers' associations existed in several industries in Britain (Beardwell \& Holden, 1997:522).

The establishment of organisations along industry lines, generally preceded the formation of central employers' associations. One of the main challenges facing employers' organisations at all structure levels, is maintaining the cohesion of employers in the face of widely diverging views among them. However, in many instances the prospect, or sometimes the actual demonstration of mutual advantages, usually overcame individual interests (Windmuller \& Gladstone, 1984:3). Despite this, the internal solidarity of employers' organisations is subject to challenges from a variety of (potential) forces including the following in particular: (1) union pressures on individual companies to break ranks; (2) the quest of employers for a competitive advantage in labour or product markets; (3) management attempts to keep a marginal company afloat; and (4) principled intercompany differences over labour relations policies (Windmuller \& Gladstone, 1984:19).

As mentioned in the introduction, both trade unions and employers' organisations in South Africa have the right to establish independently constituted bodies, to organise their own administration and activities, to participate in the establishment of federations, and to affiliate to other bodies, both locally and internationally (Bendix, 2001:118).

Although employers' associations in South Africa are established mainly for the purpose of collective bargaining with unions on bargaining councils, in recent years, many of these organisations, some of which have firmly established structures, have also acted as advisors to their members on general labour relations policy (Bendix, 1996:177). In South Africa, there are two groups of employers' organisations, namely those at national level and those at industry level. At national level, some of the organisations, such as, the South African Chamber of Business (SACOB), are not registered employers' organisations in terms of the labour legislation, and as such, do not concern themselves with direct wage negotiations with trade unions. However, through other forums to which they are affiliated, there is consultation with unions on matters of concern to its members and the wider community. Typical other organisations at national level include: Business South Africa (BSA), the Black Business Council (BBC), the National African Federated Chamber of Commerce (NAFCOC), the Afrikaanse Handelsinstituut (AHI), and the Foundation for African Business and Consumer Services (FABCOS).

On 11 October 2003, after months of intense deliberation, there was a certain degree of realignment between these groups. Six organisations formed the Chambers of Commerce and Industry South Africa (CHAMSA) and Business Unity South Africa (BUSA) (Nadlangisa, 2003:1).

The organisations merging into CHAMSA are: the AHI (formerly the Afrikaanse Handelsinstituut), the Foundation for African Business and Consumer Services (FABCOS), the National African Federated Chamber of Commerce and Industry (NAFCOC) and the South African Chamber of Business (SACOB). The four chambers will retain their independence and structures.

\section{The objectives of CHAMSA are to}

- deracialise and integrate the national chambers of commerce

- promote economic growth and development

- promote the development and growth of small and microenterprises (SMEs)

- $\quad$ promote black economic empowerment and transform the economy so that everyone can share the benefits of growth

- $\quad$ provide an organisation to represent and promote the collective views of members

- create an environment in which business can grow and prosper

CHAMSA has four seats on BUSA (www.dti.gov.za). BUSA, originated from the merger of the Black Business Council (BBC) and Business South Africa (BSA), both of which ceased to exist at the end of 2003. BUSA is fully representative in all sectors of economic activity in South Africa. It thus represents the interests of business, employers and professional people, it is also the voice of business at the National Economic Development and Labour Council (NEDLAC) (Nadlangisa, 2003:1).

There are numerous industry-based employers' organisations in South Africa. Several large ones can be 
identified such as the Steel and Engineering Industries Federation of South Africa (SEIFSA). This is a federation of 40 independent employers' organisations, and represents approximately 2700 enterprises engaged in the metal, engineering, electronics and electrical sectors, employing approximately 200000 people. Another is the Chamber of Mines (COM), which is a voluntary association of six independent mining houses which together employ 500000 people. The South African Motor Industry Employers' Association (SAMEIA) represents the interests of 8300 employers in the retail motor industry as well as vehicle component manufacturers, while the Automobile Manufacturers Employers' Organisation (AMEO) protects the interests of employers in the motor-vehicle manufacturing sector.

\section{Research methodology}

\section{Sample selection}

For this study, the International Labour Organisation (ILO) requested that in each of the 18 countries participating in the survey, the sample should consist of local enterprises and subsidiaries of multinational enterprises. From the foregoing it is clear that the companies participating in the survey can be classified as 'local companies' and 'foreign companies'. During the research project, it became obvious that no single database existed in South Africa containing the names of all employers' organisations and their members. The reason, as mentioned earlier in this paper, was the fact that two groups of employers' organisations existed, namely registered and unregistered ones. After contacting the various major role players in each of these groups, it was decided to work, where possible, with only the registered group of employers' organisations. The reason for this decision was that the information on this group could be easily obtained from the Department of Labour where they had to register.

The first step in the process involved obtaining the alphabetical list of the employers' organisations from the Department of Labour. To ensure that the sample was drawn scientifically from the population, it was decided to classify the employers' organisations within each of the letters of the alphabet according to their membership size, that is, the number of companies they represent. The classification used for this process was less than 50 companies, 50 to 99 companies, 100 to 499 companies, 500 to 999 companies, and 1000 and more companies. Since the list obtained from the Department of Labour was numbered from 1 to 259, the number applicable to each employer organisation was placed in a category. Table 1 indicates the example for alphabet letter 'A'.

Once this process had been completed, the first number in each category was drawn, resulting in approximately five employers' organisations per alphabet letter in the majority of cases. It should be noted that not all alphabet letters had employers' organisations in each of the categories. Through this process, a total of 96 employers' organisations were identified. The next step in the process involved making contact with each employer's organisation. This took place by either telephone/fax or e-mail. The organisations were requested to make available the contact details of the first 10 companies on their membership list. This did not necessarily mean the 10 biggest companies affiliated to the employers' organisation. During this process it was established that some employers' organisations had closed down, while others were not prepared to make the information available. In many cases no reasons were provided. However, a number of them were willing to help, and this resulted in 739 companies (i.e. members of employers' organisations) being identified.

Table 1: Classification method used for employers' organisations on the Department of Labour list

\begin{tabular}{l|l}
\hline \multicolumn{1}{c|}{ Membership } & $\begin{array}{c}\text { Number on Department of Labour } \\
\text { list }\end{array}$ \\
\hline Less than 50 companies & $1,2,4,5,12,13,14,15,17,19,20$ \\
\hline $50-99$ companies & $7,8,9,10,18$ \\
\hline $100-499$ companies & 6,11 \\
\hline $500-999$ companies & 3 \\
\hline 1000 and more companies & 16 \\
\hline
\end{tabular}

Because of the difficulties experienced identifying the 'local companies' through their employers' organisations, as well as the lack of information at the employers' organisations on 'foreign companies', a decision had to be made about identifying the population for the 'foreign companies' by using another method. It was subsequently decided to use an authentic 'foreign companies' database. One such database was the information contained in the 2001/2002 publication of the Commercial Intelligence Service, a division of Business Monitor International. This publication, 'Foreign Companies in South Africa' provided an alphabetical list of some 2000 foreign companies operating in South Africa. It was decided to draw the first four companies on the list under each of the alphabetical letters. A total of 104 companies were accordingly identified under the 'foreign companies' group. One drawback of following this approach, in contrast to the earlier 'local companies' list, was that no information was available to determine whether these companies were in fact members of employers' organisations. However, as explained earlier, this approach was the only option available.

\section{Survey design}

The questionnaire used for this study was based on the questionnaire provided by the International Labour Organisation (ILO) to the 18 countries participating in the survey. Because of structural problems with the questionnaire, some amendments were suggested and accepted by the ILO. The questionnaire was also extended to include questions on demographic details. The questionnaire consisted mainly of questions on the services provided by the employers' organisations to their members. These included: financial issues, management services, human resource management, labour relations and training services. Questions on client satisfaction as well as the 
frequency of contact with employers' organisations were also included.

For the majority of the questions, use was made of a 4-point Likert scale. The scale ranged from rarely/almost never (1) to a large extent/frequently (4). A score of 3 and above thus indicates frequent use of the employer organisation's services in a particular area, while a score of below 3, indicates only limited use of the services provided.

\section{Pretest of the questionnaire}

In this study, no formal pretest was conducted, but inputs were obtained from the staff in the Human Resource Management Division of the Department of Business Management at the University of South Africa. It was decided to follow this approach because the staff in this Division were specialists in the different areas covered in the questionnaire.

\section{Statistical analysis}

Descriptive statistics were used to interpret the data, for example, frequencies, percentages, means and standard deviations, as well as comparisons in the form of crosstabulations. The statistical analysis was conducted by means of the SAS programme (SAS Institute, 2000).

\section{Results}

\section{Response rate and respondent/company characteristics}

The questionnaires were mailed to all 843 companies (739 'local companies' and 104 'foreign companies') on 29 August 2003. Of these, 15 were returned by companies that were not members of an employer's organisation. This yielded an adjusted sample size of 828. A total of 125 usable questionnaires were received (19 from 'foreign companies'), representing a response rate of $15,1 \%$.

The results indicate that $28,8 \%$ of the respondents were group/divisional general managers, 28,8\% group/senior human resource managers and 4,8\%, group/senior labour relations managers, while $33,6 \%$ were senior managers either in marketing, finance or production. Senior management in their organisations thus appear to be well represented in this survey. Regarding the number of employees, 47,2\% were micro companies, (fewer than 100 employees), 35,2\% were small/medium companies (between 101-400 employees), while $17,6 \%$ were large companies (companies with more than 400 employees). In the case of the age of the companies, 6,4\% were younger than five years old, 24\% between six and 19 years old, 13,6\% between 20 and 29 years old, while 56\% were older than 30 years. Thus the majority of companies (56\%) can be regarded as fairly well established and should have well entrenched business functions such as finance, marketing, production, human resource management and labour relations. Regarding the stage of development of the company, the results indicate that $54,4 \%$ are in the mature stage of their development (i.e., the company has an established reputation and its growth rate has stabilised); $25,2 \%$ are still in the growth phase (i.e., the company has established its position in the market, and its annual sales are increasing rapidly); $17,8 \%$ have diversified their activities (i.e., the growth and profitability of the company's traditional products and services have declined and new products and areas of activities have been embarked upon to provide sustained growth and profitability); and 2,4\% of the companies are in their infancy stage (i.e., the company has recently been formed and is still establishing its products and services in the marketplace). Additional characteristics of the companies are summarised in Table 2.

\section{Table 2: Characteristics of participating companies}

\begin{tabular}{l|c|c}
\hline \begin{tabular}{l} 
Variable \\
\multicolumn{3}{c}{ Approximate annual turnover (sales and services) }
\end{tabular} & (N) & $\%$ \\
\hline Less than R1 million & 4 & 3,3 \\
\hline R1 million - R2,5 million & 9 & 7,4 \\
\hline R2,5 million - R5 million & 9 & 7,4 \\
\hline R5 million - R10 million & 12 & 9,8 \\
\hline R10 million - R25 million & 17 & 13,9 \\
\hline R25 million - R50 million & 14 & 11,5 \\
\hline More than R50 million & 57 & 46,7 \\
\hline
\end{tabular}

- Frequency missing $=3$

\begin{tabular}{l|c|c}
\hline \multicolumn{1}{c|}{ Organisation structure } & (N) & $\%$ \\
\hline relatively flat with few layers of management & 98 & 78,4 \\
\hline relatively tall with many layers of management & 18 & 14,4 \\
\hline tends to be unconventional (eg matrix) & & \\
\hline
\end{tabular}

- Length of membership of employers' organisation

\begin{tabular}{l|c|c}
\multicolumn{1}{c|}{ organisation } & (N) & $\%$ \\
\hline less than 5 years & 30 & 24,6 \\
\hline 6 to 9 years & 22 & 18,0 \\
\hline 10 to 19 years & 35 & 28,7 \\
\hline 20 to 29 years & 20 & 16,4 \\
\hline 30 years or more & & \\
\hline - Frequency missing $=3$ & 15 & 12,3 \\
\hline
\end{tabular}


Table 2: Continued

\begin{tabular}{l|c|c}
\hline \multicolumn{1}{c|}{$\begin{array}{l}\text { Proportion of employees belonging to a trade } \\
\text { union }\end{array}$} & (N) & $\%$ \\
\hline $0 \%$ & 26 & 20,8 \\
\hline $1-10 \%$ & 12 & 9,6 \\
\hline $11-25 \%$ & 15 & 12,0 \\
\hline $26-50 \%$ & 25 & 20,0 \\
\hline $51-75 \%$ & 27 & 21,6 \\
\hline $76-100 \%$ & 20 & 16,0 \\
\hline
\end{tabular}

- Sector of industry to which the company belongs

\begin{tabular}{l|c|c}
\hline & $\mathbf{( N )}$ & $\mathbf{( \% )}$ \\
\hline Agriculture, hunting, forestry, fishing & 6 & 4,8 \\
\hline Energy and water & 2 & 1,6 \\
\hline $\begin{array}{l}\text { Chemical products; extraction and processing of nonenergy } \\
\text { minerals }\end{array}$ & 7 & 5,6 \\
\hline $\begin{array}{l}\text { Metal manufacturing; mechanical, electrical and instrument } \\
\text { engineering; office and data-processing machinery }\end{array}$ & 43 & 34,4 \\
\hline $\begin{array}{l}\text { Other manufacturing, (eg food, drink and tobacco; textiles; } \\
\text { clothing; paper, printing and publishing; processing of } \\
\text { rubber and plastics, etc) }\end{array}$ & 23 & 18,4 \\
\hline Building and civil engineering & & \\
\hline Retail and distribution; hotels; catering; repairs & 11 & 8,8 \\
\hline $\begin{array}{l}\text { Transport and Communication (eg rail, postal services, } \\
\text { telecoms, etc) }\end{array}$ & 0 & 0,4 \\
\hline $\begin{array}{l}\text { Banking; finance; insurance; business services (eg } \\
\text { consultancies, PR and advertising, Law firms, etc) }\end{array}$ & 3 & 2,4 \\
\hline Personal, domestic, recreational services & 1 & 0,8 \\
\hline Health services & 2 & 1,6 \\
\hline $\begin{array}{l}\text { Other services (eg television and radio, R \& D, charities, } \\
\text { etc) }\end{array}$ & 0 & 0 \\
\hline Education (including universities and further education) & 0 & 0 \\
\hline $\begin{array}{l}\text { Social services } \\
\text { Public administration. }\end{array}$ & 0 & 0 \\
\hline
\end{tabular}

* Because of some of the companies' diversity actions, they had problems placing their company in a specific sector.

\section{Frequency of contact with employers' organisations}

In the case of $29,6 \%$ of the companies, the contact takes place on a monthly basis, $18,4 \%$ on a three monthly basis, $15,2 \%$ on a yearly basis, $14,4 \%$ on a six-monthly basis, $7,2 \%$ on a weekly basis, $1,6 \%$ on a daily basis, and in the case of $10,4 \%$, there is no contact at all. One could thus say that only a small percentage of companies $(38,4 \%)$ contact their employers' organisations regularly (i.e. daily, weekly and monthly).
Nature of contact between the company and employers' organisation

As indicated earlier, five main areas of service provision were identified, namely: (1) financial issues, (2) management services, (3) human resource management, (4) labour relations issues and (5) training services. A number of subcomponents for each of these areas were generated to establish the exact nature of the contact in each of these components. Since comparisons in the form of crosstabulations could shed additional light on the underlying issues regarding the provision of services to the clients of the employers' organisations, it was decided to make comparisons between the size of the company and the nature of the contact with the employers' organisations. As indicated earlier, companies with fewer than 100 employees would be regarded as micro companies, 101 to 400 employees as small/medium companies, and 401+ employees, as large companies. Tables 3 to 7 in the Appendix of this paper show the comparisons between the different sizes of companies and the individual subcomponents of the five main areas mentioned earlier. We will now examine each of these areas separately.

\section{Financial services}

Six items appeared in this construct. The Cronbach's Alpha was high at 0,879 indicating reliable measures for this construct. A number of interesting facts regarding the financial services component are evident in Table 3, although the contact rate is extremely low. As far as the micro companies are concerned, contact with the employers' organisation seems to focus on the raising of domestic capital, while in the case of the large companies, it is more concerned with raising foreign capital. This is understandable because the micro companies do not always have easy access to domestic capital as do some of the large companies through share issues. The large companies' contact also focuses more on business expansion, while small/medium companies tend to contact the employers' organisation in the area of mergers and acquisitions and joint ventures and alliances. This is not unusual because small/medium companies are often the target of takeovers by large companies. As far as government grants and subsidies are concerned, the contact will stem mainly from the small/medium companies because they do not always have the expertise on how such matters work, and may thus require assistance.

\section{Management services}

As in the case of Financial services, the reliability of the construct was very high with a Cronbach's Alpha of 0,897. Fourteen items were included in this construct. A number of interesting facts regarding the management services component are evident in Table 4, although the contact rate is again extremely low. It would appear that in the area of public relations, the large companies tend to contact the employers' organisations on this matter. This is understandable since controversy surrounding major companies tends to receive more media attention than that surrounding smaller ones. This is again reflected in an issue which is closely related to public relations, namely media 
communication where the large companies also tend to be more prominent. In the area of lobbying, the finding is that the large companies tend to contact the employers' organisations. A possible reason for this could be the attitude of large companies that they like to influence matters that are important to them. This approach is also evident in major companies internationally. Purchasing, IT communications and conference management tend to be areas about which micro companies contact their employers' organisations. Since many micro companies are family owned, they sometimes do not have the expertise in these areas, and thus require assistance. The same applies to packaging. In the case of project management, the large companies tend to contact their employers' organisations. This is understandable because they are involved in major projects where the need for this expertise is the greatest. The same applies to business management and supply chain management. In the area of environmental issues, the large companies tend to contact their employers' organisation. The reason for this could well be the problem many of them have with the disposal of toxic waste, especially in the manufacturing area. They are constantly reminded of their responsibility in this regard by the many groups fighting for a cleaner and safer environment. As far as transport and distribution are concerned, the large companies also tend to be prominent here. This is understandable since there has been a major debate in South Africa regarding the overuse of the country's roads by these companies, as well as problems involving the safety of their vehicles. In the area of corporate governance and legal services, the large companies again stand out. Corporate governance and legal services tend to be important with the renewed interest by the broader public since the recent publication of the King I and II reports on corporate governance in South Africa.

\section{Human resource management}

Ten items appeared in this construct. Again, the Cronbach's Alpha was high at 0,895 indicating reliable measures for this construct. A number of interesting facts regarding the human resource management component emerge from Table 5 , although the usage here is also limited. In the area of contracting out services, the large companies tend to contact their employers' organisations on this matter. This is understandable because jobs in the company are in jeopardy when this happens and companies need to be sensitive about the issue. The international trend of contracting out non-core services has also become popular in South Africa, especially among the large companies which are continuously looking for ways to reduce their operating costs. An issue which tends to be on par amongst the large and small/medium companies is flexible working advice. This issue affects any reasonable size company wanting to utilise its staff optimally. In the area of productivity improvement, the large companies tend to stand out. Productivity impacts directly on production costs and needs to be addressed on an ongoing basis. It is inevitable that large companies would have more problems in this area compared with smaller ones. With the introduction of numerous new labour laws since 1994, the work environment (especially, the relationship between management and employees) has become a vital area for companies, especially the employment contracts into which they enter. Advice in this regard especially for large companies with numerous staff, is critical to avoid legal actions. Another issue is that of health and safety. Because of a few major accidents, especially in the mining industry, the government introduced new guidelines for companies. It is not surprising therefore, that large companies tend to contact their employers' organisations for advice in this area because of the large number of people they employ. The same applies to drug and alcohol concerns. In the case of Aids in the workplace, small/medium companies seem to contact their employers' organisations on this matter. This is not surprising as they do not have a large staff component and the number of employees affected by HIV/Aids can impact negatively on their growth. In the area of employment equity, the problem appears to be with the small/medium size companies as well. Following the introduction of the employment equity legislation during 1998, the government laid down a number of important requirements to be met by organisations such as drawing up an employment equity plan to be submitted to the Department of Labour. The results of the survey indicate that small/medium companies tend to have problems in this area, which has also been confirmed by the press in South Africa. As far as the issue of change management is concerned it appears that large companies tend to be affected the most in this regard. This is not surprising due to the large number of employees they have and the impact that change management can have on the employees. An issue which tends to be on a par amongst large and micro companies is that of recruitment. Although these companies are on the opposite end of the continuum, both struggle to obtain employees in specific areas of expertise and would thus need some assistance/advice in this regard.

\section{Labour relations issues}

Seven items relating to labour relations issues were included here. The Cronbach's Alpha for these was 0,892, again a very high indication of construct reliability. A number of interesting facts regarding the labour relations component emerge from Table 6, although a low usage factor is again evident here. In the area of collective bargaining, the intensity of contact appears to be between the employers' organisation and the small/medium companies. This is not surprising as they do not, like many large companies, have permanent IR officers which can assist them in this regard. In the area of labour relations advice the large companies take the lead, followed by the small/medium companies, and lastly the micro companies. This is not surprising, especially when all avenues have been tried and a major strike is looming, additional advice is normally required urgently by these companies. Related to this is the issue of employee consultation also important with large companies. An area in which small/medium companies tend to need assistance is communication with employees. This is an important process and could be a result of the provisions in the Labour Relations Act regarding the joint consultation between management and employees on a number of issues mentioned in the Act. For the area of pay and benefit information, the large companies are more prominent. This is understandable as the management of this issue tends to be complex in this type of company. On the other hand, in the area of pay and benefit advice, the small/medium 
companies appear to feature more prominent. This is understandable as they, in many cases, do not have the expertise in this area. In the area of redundancy management, the large companies tend to contact the employers' organisation on this issue. This ties in with the previous finding on the contracting out of services (HR component) which is fairly popular among large companies and has an impact on jobs.

\section{Training services}

Concerning Training services four items appeared. Again, the Cronbach's Alpha was high at 0,862 indicating reliable measures for this construct. A number of interesting facts regarding the training services component emerge from Table 7, but once again with a low volume of usage. One way for a company to increase its chances of its managers being effective, is through management training. Management training focuses more on providing specific skills or knowledge that can be immediately applied in a company, and/or to a specific position or set of positions in an organisation, such as middle managers. In large organisations with many managerial positions this poses a huge challenge. It is thus not surprising that large companies tend to contact the employers' organisations in this regard. South Africa has a serious skills shortage, especially at middle and top management level, which will inevitably place a greater burden on all concerned. A profession is an occupation based on an abstract body of knowledge. Examples of professions include medicine, law, accounting, teaching and engineering. The domain of knowledge that an individual must master in order to be officially considered a professional in a given field, is typically defined by the professional association. In many professions credentials such as a licence or certificate is required for the individual to practise in that field. Most companies employ lawyers and accountants and it is thus not surprising that the results of this study indicate that the large companies contact their employers' organisations in this regard (professional training). This is understandable because they tend to have more of these types of employees, than the other companies. In the case of staff training, the large companies tend to contact their employers' organisation, while the results for the micro and small/medium companies are on par. Training is essential for all employees, because workers need new or significantly expanded skills to keep up with the demands of their jobs. Technical training is a generic term that can encompass a wide range of programmes. The following categories of technical training programmes can be identified, for example: learnerships (apprenticeship training), computer training, technical skills/knowledge training, safety training and quality training (Desimone, Werner \& Harris, 2002: 323-354). The results show that it is inevitable for large companies (ie, with many employees) to make contact with the employers' organisation in this regard. There is a dire need for technical training in these types of companies and assistance is thus inevitable.

\section{Client satisfaction}

Seven items were included here. As in the case of the previous constructs the reliability of the construct was very high with a Cronbach's Alpha of 0,907. As with the previous aspect, it was also decided to make some comparisons between the issue of client satisfaction and the size of the company. The results are indicted in Table 8 in the Appendix.

The following interesting facts emerge regarding client satisfaction. As far as the relationship between the employers' organisation and the different types of companies is concerned, the large companies appear to be the most satisfied with the relationship, followed by the micro companies and then the small/medium companies. This trend also emerged regarding the overall effectiveness/efficiency of the employers' organisation as rated by the companies. An issue which tend to be on par amongst the companies is that of the reliability of information provided by the employers' organisations to their members. In this area there appears to be no problem which is encouraging. However, in the area of accessibility to information, reply time, and the professionalism of the staff of the employers' organisation, the micro companies seem to be the most satisfied, while in the area of accessibility to staff, the large companies are the most satisfied. Thus, although the relationship seems satisfactory between the large companies and their employers' organisations, issues relating to reply time, accessibility to information and professionalism of staff seems problematic. Regarding the small/medium companies, the accessibility to staff, the overall effectiveness/efficiency of their employers' organisations, accessibility to information, reply time and the professionalism of staff, seem to be a problem. While in the case of the micro companies, the issues relating to the accessibility to staff, the relationship between the companies and the employers' organisation and the overall effectiveness/efficiency seems problematic.

\section{Conclusions and recommendations}

The primary objective of this study was, firstly, to establish to what extent members (companies) make use of the services of employers' organisations, and secondly, to what extent they were satisfied with the service they receive from their employers' organisations.

Although there is an extremely positive relationship between the companies and their employers' organisations (the large companies being the best), there appears to be some weakness in the area of the reply time, accessibility of information and the professionalism of the employers' organisation staff, in the case of the large companies. In the case of the small/medium companies the following have been identified as weaknesses; overall effectiveness/ efficiency of the employers' organisation, the relationship between the company and its organisation, the accessibility to information and staff, reply time, and the professionalism of the employers' organisation staff. While in the case of the micro companies, the following appear to be weaknesses: overall effectiveness/efficiency of its employers' organisation, relationship between the company and its organisation and accessibility to staff. The employers' organisations thus need to address these problems with regard to these different types of companies. 
Since issues of productivity, training, accessibility to finance, global competition and the influence of technology seem to be the challenges facing companies today, it is worrying that only a limited number of companies contact their employers' organisations for advice/assistance in this regard. Although limited contact was made, areas which stand out include human resource management, labour relations and training services. Perhaps it is necessary for the employers' organisations to embark on an awareness campaign amongst their members regarding the services they can provide. Some proactive action thus seems necessary.

A problem experienced during this research was the lack of information on employers' organisations and their members. These organisations should make an effort to become better known to the broader public in South Africa through, for example, well-designed websites. This could lead to expert consulting advice being offered to them.

This study shows that the relationship between labour and management has changed dramatically over the years and will continue to do so in the future. South Africa's isolation is a thing of the past, and the impact of international influences on business and labour cannot be ignored. This requires a change in some of the traditional roles played in the past, especially from the side of the employers' organisations. One method to achieve this is through the reengineering of their processes.

\section{Acknowledgements}

The research team would like to express their sincere thanks to the International Labour Organisation, Genève, Switzerland and the Research and Bursaries Committee of the College of Economic and Management Sciences, at the University of South Africa, for their financial assistance. We would also like to thank Ms M Coetzee, M Holtzhausen and $\mathrm{J}$ Botha from the Department of Business Management at the University of South Africa, for their assistance with this project.

\section{References}

Aaker, D.A., Kumar, V. \& Day, G.S. 1995. Marketing research. $5^{\text {th }}$ Edition. New York: Wiley.

Beardwell, I. \& Holden, L. 1997. Human resource management: A contemporary perspective. $2^{\text {nd }}$ Edition. London: Pitman (a division of Pearson Professional).

Bendix, S. 1996. Industrial relations in the new South Africa. $3^{\text {rd }}$ Edition. Cape Town: Juta.

Bendix, S. 2001. Industrial relations in the new South Africa. $4^{\text {th }}$ Edition. Cape Town: Juta.

Department of Trade and Industries. www.dti.gov.za.

Desimone, R.L., Werner, J.M. \& Harris, D.M. 2002. Human resource development. $3^{\text {rd }}$ Edition. Sea Harbor Drive, Orlando: Harcourt.
Dessler, G. 2000. Human resource management. Upper Saddle River, NJ: Prentice-Hall.

Finnemore, M. \& Van Rensburg, R. 2002. Contemporary labour relations. 2nd Edition. Durban: Butterworths.

Labour Relations Act, No 66 of 1995, Government Gazette, 366(16861) 13 December 1995.

Nadlangisa, S. 2003. 'Finally SA business speaks with one voice'. Sunday Times-Business Times, 12 October:1. (www.sundaytimes.co.za)

SAS Institute. 2000. The SAS System for Windows: Release 8.1. Cary, NC: SAS Institute.

Saunders, M.N.K., Lewis, P. \& Thornhill, A. 1997. Research methods for business students. London: Pitman.

Venter, R. (Ed.). 2003. Labour relations in South Africa. Revised edition. Cape Town: Oxford University Press.

Windmuller, J.P. \& Gladstone, A. (Eds.). 1984. Employers' associations and industrial relations: A comparative study. Oxford: Clarendon Press. 


\section{APPENDIX}

Table 3: Comparison between company size and responses to financial services

\begin{tabular}{|c|c|c|c|c|c|c|}
\hline \multirow[t]{2}{*}{ Financial services } & \multirow[t]{2}{*}{ Company size } & \multirow[t]{2}{*}{$\mathbf{N}$} & \multicolumn{4}{|c|}{ Frequencies (\%) } \\
\hline & & & Rarely & Infrequently & Moderately & Frequently \\
\hline \multirow[t]{4}{*}{ Raising domestic capital } & Micro & 56 & 89,3 & 5,4 & 5,4 & 0 \\
\hline & Small \& med & 41 & 95,1 & 4,9 & 0,0 & 0,0 \\
\hline & Large & 21 & 90,5 & 4,8 & 4,8 & 0,0 \\
\hline & Total & 118 & 91,5 & 5,1 & 3,4 & 0,0 \\
\hline \multirow[t]{4}{*}{ Raising foreign capital } & Micro & 56 & 94,6 & 0,0 & 3,6 & 1,8 \\
\hline & Small \& med & 41 & 97,6 & 2,4 & 0,0 & 0,0 \\
\hline & Large & 20 & 90,0 & 5,0 & 5,0 & 0,0 \\
\hline & Total & 117 & 94,9 & 1,7 & 2,6 & 0,9 \\
\hline \multirow[t]{4}{*}{ Business expansion } & Micro & 55 & 78,2 & 12,7 & 9,1 & 0,0 \\
\hline & Small \& med & 41 & 78,1 & 17,1 & 2,4 & 2,4 \\
\hline & Large & 21 & 76,2 & 4,8 & 14,3 & 4,8 \\
\hline & Total & 117 & 77,8 & 12,8 & 7,7 & 1,7 \\
\hline \multirow[t]{4}{*}{ Mergers and acquisitions } & Micro & 53 & 92,5 & 3,8 & 3,8 & 0,0 \\
\hline & Small \& med & 40 & 87,5 & 7,5 & 2,5 & 0,9 \\
\hline & Large & 20 & 95,0 & 0,0 & 5,0 & 0,0 \\
\hline & Total & 113 & 91,2 & 4,4 & 3,5 & 0,9 \\
\hline \multirow[t]{4}{*}{ Joint ventures and alliances } & Micro & 55 & 90,9 & 3,6 & 5,5 & 0,0 \\
\hline & Small \& med & 41 & 75,6 & 9,8 & 12,2 & 2,4 \\
\hline & Large & 20 & 80,0 & 10,0 & 10,0 & 0,0 \\
\hline & Total & 116 & 83,6 & 6,9 & 8,6 & 0,9 \\
\hline \multirow[t]{4}{*}{ Government grants and subsidies } & Micro & 55 & 80,0 & 10,9 & 3,6 & 5,5 \\
\hline & Small \& med & 41 & 58,5 & 26,8 & 9,8 & 4,9 \\
\hline & Large & 20 & 60,0 & 15,0 & 15,0 & 10,0 \\
\hline & Total & 116 & 69,0 & 17,2 & 7,8 & 6,0 \\
\hline
\end{tabular}

*Missing values excluded

Key to Tables 3-7:

although the contact rate is extremely low in all cases, these companies tend to contact their employer organisations on these issues. 
Table 4: Comparison between company size and responses to management services

\begin{tabular}{|c|c|c|c|c|c|c|}
\hline \multirow[t]{2}{*}{ Management services } & \multirow[t]{2}{*}{ Company size } & \multirow[t]{2}{*}{$\mathbf{N}$} & \multicolumn{4}{|c|}{ Frequencies (\%) } \\
\hline & & & Rarely & Infrequently & Moderately & Frequently \\
\hline \multirow[t]{4}{*}{ Public relations } & Micro & 57 & 61,4 & 21,1 & 14,1 & 3,5 \\
\hline & Small \& med & 42 & 64,3 & 21,4 & 11,9 & 2,4 \\
\hline & Large & 20 & 60,0 & 25,0 & 10,0 & 50,0 \\
\hline & Total & 119 & 62,2 & 21,9 & 12,6 & 3,4 \\
\hline \multirow[t]{4}{*}{ Media communication } & Micro & 57 & 70,2 & 15,8 & 7,0 & 7,0 \\
\hline & Small \& med & 42 & 69,1 & 16,7 & 14,3 & 0,0 \\
\hline & Large & 20 & 65,0 & 30,0 & 0,0 & 5,0 \\
\hline & Total & 119 & 68,9 & 18,5 & 8,4 & 4,2 \\
\hline \multirow[t]{4}{*}{ Lobbying } & Micro & 57 & 77,2 & 12,3 & 7,0 & 3,5 \\
\hline & Small \& med & 41 & 58,5 & 21,9 & 12,2 & 7,3 \\
\hline & Large & 20 & 55,0 & 15,0 & 15,0 & 15,0 \\
\hline & Total & 118 & 66,9 & 16,1 & 10,2 & 6,8 \\
\hline \multirow[t]{4}{*}{ Purchasing } & Micro & 57 & 77,2 & 12,3 & 8,8 & 1,8 \\
\hline & Small \& med & 42 & 85,7 & 7,1 & 7,1 & 0,0 \\
\hline & Large & 20 & 90,0 & 5,0 & 5,0 & 0,0 \\
\hline & Total & 119 & 82,4 & 9,2 & 7,6 & 0,8 \\
\hline \multirow[t]{4}{*}{ Packaging } & Micro & 57 & 85,9 & 8,8 & 3,5 & 1,7 \\
\hline & Small \& med & 41 & 92,7 & 4,8 & 0,0 & 2,4 \\
\hline & Large & 20 & 95,0 & 5,0 & 0,0 & 0,0 \\
\hline & Total & 118 & 89,8 & 6,8 & 1,7 & 1,7 \\
\hline \multirow[t]{4}{*}{ Project management } & Micro & 57 & 82,5 & 7,0 & 8,7 & 1,8 \\
\hline & Small \& med & 42 & 88,1 & 7,1 & 2,4 & 2,4 \\
\hline & Large & 19 & 78,9 & 15,8 & 0,0 & 5,3 \\
\hline & Total & 118 & 83,9 & 8,5 & 5,1 & 2,5 \\
\hline
\end{tabular}


Table 4: Comparison between company size and responses to management services

\begin{tabular}{|c|c|c|c|c|c|c|}
\hline \multirow[t]{2}{*}{ Management services } & \multirow[t]{2}{*}{ Company size } & \multirow[t]{2}{*}{$\mathbf{N}$} & \multicolumn{4}{|c|}{ Frequencies (\%) } \\
\hline & & & Rarely & Infrequently & Moderately & Frequently \\
\hline \multirow[t]{4}{*}{ Business management } & Micro & 58 & 74,1 & 10,3 & 12,1 & 3,5 \\
\hline & Small \& med & 42 & 78,6 & 14,3 & 7,1 & 0,0 \\
\hline & Large & 21 & 71,4 & 14,3 & 9,5 & 4,8 \\
\hline & Total & 121 & 75,2 & 12,4 & 9,9 & 2,5 \\
\hline \multirow[t]{4}{*}{ Supply chain management } & Micro & 56 & 85,7 & 10,7 & 1,8 & 1,8 \\
\hline & Small \& med & 41 & 87,8 & 12,2 & 0,0 & 0,0 \\
\hline & Large & 19 & 84,2 & 15,8 & 0,0 & 0,0 \\
\hline & Total & 116 & 86,2 & 12,1 & 0,86 & 0,86 \\
\hline \multirow[t]{4}{*}{ Environmental issues } & Micro & 58 & 75,9 & 8,6 & 13,8 & 1,7 \\
\hline & Small \& med & 41 & 65,9 & 19,5 & 14,6 & 0,0 \\
\hline & Large & 21 & 52,4 & 33,3 & 9,5 & 4,8 \\
\hline & Total & 120 & 68,3 & 16,7 & 13,3 & 1,7 \\
\hline \multirow[t]{4}{*}{ Transport and distribution } & Micro & 57 & 87,7 & 5,3 & 5,3 & 1,8 \\
\hline & Small \& med & 41 & 85,4 & 14,6 & 0,0 & 0,0 \\
\hline & Large & 19 & 78,9 & 21,1 & 0,0 & 0,0 \\
\hline & Total & 117 & 85,5 & 11,1 & 2,6 & 0,9 \\
\hline \multirow[t]{4}{*}{ IT and communications } & Micro & 57 & 85,9 & 5,3 & 7,0 & 1,8 \\
\hline & Small \& med & 41 & 95,1 & 4,8 & 0,0 & 0,0 \\
\hline & Large & 19 & 94,7 & 5,3 & 0,0 & 0,0 \\
\hline & Total & 117 & 90,6 & 5,1 & 3,4 & 0,9 \\
\hline \multirow[t]{4}{*}{ Corporate governance } & Micro & 58 & 81,0 & 8,6 & 10,3 & 0,0 \\
\hline & Small \& med & 41 & 70,7 & 17,1 & 12,2 & 0,0 \\
\hline & Large & 20 & 50,0 & 45,0 & 50,0 & 0,0 \\
\hline & Total & 119 & 72,3 & 17,7 & 10,0 & 0,0 \\
\hline
\end{tabular}


Table 4: Comparison between company size and responses to management services

\begin{tabular}{|c|c|c|c|c|c|c|}
\hline \multirow[t]{2}{*}{ Management services } & \multirow[t]{2}{*}{ Company size } & \multirow[t]{2}{*}{$\mathbf{N}$} & \multicolumn{4}{|c|}{ Frequencies (\%) } \\
\hline & & & Rarely & Infrequently & Moderately & Frequently \\
\hline \multirow[t]{4}{*}{ Conference management } & Micro & 57 & 77,2 & 17,5 & 3,5 & 1,8 \\
\hline & Small \& med & 41 & 80,5 & 14,6 & 4,8 & 0,0 \\
\hline & Large & 19 & 84,2 & 5,3 & 5,3 & 5,3 \\
\hline & Total & 117 & 79,5 & 14,5 & 4,3 & 1,7 \\
\hline \multirow[t]{4}{*}{ Legal services } & Micro & 57 & 59,7 & 26,3 & 7,0 & 7,0 \\
\hline & Small \& med & 41 & 60,9 & 21,9 & 14,6 & 2,4 \\
\hline & Large & 20 & 50,0 & 25,0 & 20,0 & 5,0 \\
\hline & Total & 118 & 58,5 & 25,6 & 11,8 & 5,1 \\
\hline
\end{tabular}

\footnotetext{
*Missing values excluded
} 
Table 5: Comparison between company size and responses to human resource management

\begin{tabular}{|c|c|c|c|c|c|c|}
\hline \multirow{2}{*}{$\begin{array}{l}\text { Human Resource } \\
\text { Management }\end{array}$} & \multirow[t]{2}{*}{ Company size } & \multirow[t]{2}{*}{$\mathbf{N}$} & \multicolumn{4}{|c|}{ Frequencies (\%) } \\
\hline & & & Rarely & Infrequently & Moderately & Frequently \\
\hline \multirow[t]{4}{*}{ Contracting out services } & Micro & 58 & 75,9 & 13,8 & 6,9 & 3,5 \\
\hline & Small \& med & 42 & 73,8 & 14,3 & 9,5 & 2,4 \\
\hline & Large & 20 & 65,0 & 25,0 & 5,0 & 5,0 \\
\hline & Total & 120 & 73,3 & 15,8 & 7,5 & 3,3 \\
\hline \multirow[t]{4}{*}{ Change management } & Micro & 57 & 80,7 & 14,0 & 3,5 & 1,8 \\
\hline & Small \& med & 42 & 83,3 & 9,5 & 4,8 & 2,4 \\
\hline & Large & 20 & 75,0 & 20,0 & 5,0 & 0,0 \\
\hline & Total & 119 & 80,7 & 13,5 & 4,2 & 1,7 \\
\hline \multirow{4}{*}{$\begin{array}{l}\text { Productivity improvement } \\
\text { advice }\end{array}$} & Micro & 59 & 76,3 & 11,9 & 11,9 & 0,0 \\
\hline & Small \& med & 42 & 71,4 & 19,0 & 4,8 & 4,8 \\
\hline & Large & 20 & 35,0 & 45,0 & 15,0 & 5,0 \\
\hline & Total & 121 & 67,8 & 19,8 & 9,9 & 2,5 \\
\hline \multirow[t]{4}{*}{ Flexible working advice } & Micro & 58 & 65,5 & 24,1 & 10,3 & 0,0 \\
\hline & Small \& med & 42 & 57,1 & 26,2 & 11,9 & 4,8 \\
\hline & Large & 19 & 57,9 & 31,6 & 5,3 & 5,3 \\
\hline & Total & 119 & 61,3 & 26,1 & 10,1 & 2,5 \\
\hline \multirow[t]{4}{*}{ Employment contracts } & Micro & 58 & 48,3 & 27,6 & 17,2 & 6,9 \\
\hline & Small \& med & 42 & 45,2 & 19,1 & 26,2 & 9,5 \\
\hline & Large & 20 & 40,0 & 30,0 & 20,0 & 10,0 \\
\hline & Total & 120 & 45,8 & 25,0 & 20,8 & 8,3 \\
\hline \multirow[t]{4}{*}{ Safety and health } & Micro & 58 & 48,3 & 25,9 & 18,9 & 6,9 \\
\hline & Small \& med & 42 & 52,4 & 26,2 & 19,1 & 2,4 \\
\hline & Large & 21 & 38,1 & 28,6 & 28,6 & 4,8 \\
\hline & Total & 121 & 47,9 & 26,5 & 20,7 & 4,9 \\
\hline
\end{tabular}


Table 5: Comparison between company size and responses to human resource management

\begin{tabular}{|c|c|c|c|c|c|c|}
\hline \multirow{2}{*}{$\begin{array}{l}\text { Human Resource } \\
\text { Management }\end{array}$} & \multirow[t]{2}{*}{ Company size } & \multirow[t]{2}{*}{$\mathbf{N}$} & \multicolumn{4}{|c|}{ Frequencies (\%) } \\
\hline & & & Rarely & Infrequently & Moderately & Frequently \\
\hline \multirow[t]{4}{*}{ Aids at work } & Micro & 58 & 63,8 & 20,7 & 13,8 & 1,7 \\
\hline & Small \& med & 42 & 47,6 & 28,6 & 21,4 & 2,4 \\
\hline & Large & 22 & 50,0 & 22,7 & 18,1 & 9,1 \\
\hline & Total & 122 & 55,7 & 23,8 & 17,2 & 3,3 \\
\hline \multirow[t]{4}{*}{ Drugs and alcohol issues } & Micro & 59 & 81,4 & 11,9 & 5,1 & 1,7 \\
\hline & Small \& med & 42 & 73,8 & 21,4 & 2,4 & 2,4 \\
\hline & Large & 20 & 60,0 & 20,0 & 15,0 & 5,0 \\
\hline & Total & 121 & 75,2 & 16,5 & 5,8 & 2,5 \\
\hline \multirow[t]{4}{*}{ Recruitment } & Micro & 59 & 76,3 & 18,6 & 5,1 & 0,0 \\
\hline & Small \& med & 42 & 80,9 & 11,9 & 4,8 & 2,4 \\
\hline & Large & 21 & 76,2 & 23,8 & 0,0 & 0,0 \\
\hline & Total & 122 & 77,9 & 17,2 & 4,1 & 0,8 \\
\hline \multirow[t]{4}{*}{ Employment equity issues } & Micro & 59 & 54,2 & 28,8 & 13,6 & 3,4 \\
\hline & Small \& med & 42 & 40,5 & 35,7 & 11,9 & 11,9 \\
\hline & Large & 20 & 55,0 & 30,0 & 10,0 & 5,0 \\
\hline & Total & 121 & 49,6 & 31,4 & 12,4 & 6,6 \\
\hline
\end{tabular}

\footnotetext{
*Missing values excluded
} 
Table 6: Comparison between company size and responses to labour relations issues

\begin{tabular}{|c|c|c|c|c|c|c|}
\hline \multirow[t]{2}{*}{ Labour relations issues } & \multirow[t]{2}{*}{ Company size } & \multirow[t]{2}{*}{$\mathbf{N}$} & \multicolumn{4}{|c|}{ Frequencies (\%) } \\
\hline & & & Rarely & Infrequently & Moderately & Frequently \\
\hline \multirow[t]{4}{*}{ Collective bargaining } & Micro & 59 & 38,7 & 20,3 & 15,3 & 25,4 \\
\hline & Small \& med & 43 & 11,6 & 16,2 & 20,9 & 51,2 \\
\hline & Large & 22 & 22,7 & 9,0 & 22,7 & 45,5 \\
\hline & Total & 124 & 26,6 & 16,9 & 18,5 & 37,9 \\
\hline \multirow[t]{4}{*}{ Employee consultation } & Micro & 59 & 61,0 & 27,1 & 10,2 & 1,7 \\
\hline & Small \& med & 44 & 40,9 & 27,3 & 15,9 & 15,9 \\
\hline & Large & 21 & 38,1 & 33,3 & 14,3 & 14,3 \\
\hline & Total & 124 & 50,0 & 28,2 & 12,9 & 8,9 \\
\hline \multirow{4}{*}{$\begin{array}{l}\text { Communication with } \\
\text { employees }\end{array}$} & Micro & 59 & 54,2 & 30,5 & 13,6 & 1,7 \\
\hline & Small \& med & 44 & 47,7 & 31,8 & 13,6 & 6,9 \\
\hline & Large & 21 & 52,4 & 33,3 & 9,5 & 4,8 \\
\hline & Total & 124 & 51,6 & 31,5 & 12,9 & 4,0 \\
\hline \multirow[t]{4}{*}{ Pay and benefit information } & Micro & 59 & 38,9 & 27,1 & 16,9 & 16,9 \\
\hline & Small \& med & 44 & 31,8 & 20,5 & 29,6 & 18,2 \\
\hline & Large & 22 & 27,3 & 36,4 & 9,1 & 27,3 \\
\hline & Total & 125 & 34,4 & 26,4 & 20,0 & 19,2 \\
\hline \multirow[t]{4}{*}{ Pay and benefit advice } & Micro & 59 & 44,1 & 25,4 & 16,9 & 13,6 \\
\hline & Small \& med & 44 & 40,9 & 20,5 & 22,7 & 15,9 \\
\hline & Large & 22 & 45,5 & 18,2 & 4,6 & 31,8 \\
\hline & Total & 125 & 43,2 & 22,4 & 16,8 & 17,6 \\
\hline \multirow[t]{4}{*}{ Labour relations advice } & Micro & 59 & 37,3 & 25,4 & 22,0 & 15,3 \\
\hline & Small \& med & 44 & 27,3 & 29,6 & 25,0 & 18,2 \\
\hline & Large & 22 & 22,7 & 22,7 & 27,3 & 27,3 \\
\hline & Total & 125 & 31,2 & 26,4 & 24,0 & 18,4 \\
\hline \multirow[t]{4}{*}{ Redundancy management } & Micro & 59 & 61,0 & 22,0 & 11,9 & 5,1 \\
\hline & Small \& med & 44 & 54,6 & 29,6 & 4,6 & 11,4 \\
\hline & Large & 21 & 38,1 & 28,6 & 9,5 & 23,8 \\
\hline & Total & 124 & 54,8 & 25,5 & 8,9 & 10,4 \\
\hline
\end{tabular}


Table 7: Comparison between company size and responses to training services

\begin{tabular}{|c|c|c|c|c|c|c|}
\hline \multirow[t]{2}{*}{ Training services } & \multirow[t]{2}{*}{ Company size } & \multirow[t]{2}{*}{$\mathbf{N}$} & \multicolumn{4}{|c|}{ Frequencies (\%) } \\
\hline & & & Rarely & Infrequently & Moderately & Frequently \\
\hline \multirow[t]{4}{*}{ Management training } & Micro & 59 & 72,9 & 20,3 & 6,8 & 0,0 \\
\hline & Small \& med & 43 & 62,8 & 16,3 & 11,6 & 9,3 \\
\hline & Large & 21 & 42,9 & 28,6 & 23,8 & 4,8 \\
\hline & Total & 123 & 64,2 & 20,3 & 11,4 & 4,1 \\
\hline \multirow[t]{4}{*}{ Professional training } & Micro & 59 & 72,8 & 18,6 & 6,8 & 1,7 \\
\hline & Small \& med & 42 & 76,2 & 9,5 & 9,5 & 4,8 \\
\hline & Large & 20 & 50,0 & 50,0 & 0,0 & 0,0 \\
\hline & Total & 121 & 70,3 & 20,7 & 6,6 & 2,5 \\
\hline \multirow[t]{4}{*}{ Staff training } & Micro & 59 & 59,3 & 16,9 & 15,3 & 8,5 \\
\hline & Small \& med & 42 & 59,5 & 19,1 & 16,7 & 4,8 \\
\hline & Large & 21 & 38,1 & 42,9 & 14,3 & 4,8 \\
\hline & Total & 122 & 55,7 & 22,1 & 15,6 & 6,6 \\
\hline \multirow[t]{4}{*}{ Technical training } & Micro & 59 & 67,8 & 16,9 & 6,8 & 8,5 \\
\hline & Small \& med & 42 & 71,4 & 11,9 & 11,9 & 4,8 \\
\hline & Large & 21 & 28,6 & 14,3 & 47,6 & 9,5 \\
\hline & Total & 122 & 62,3 & 14,8 & 15,6 & 7,4 \\
\hline
\end{tabular}

\footnotetext{
*Missing values excluded
} 
Table 8: Comparison between company size and client satisfaction

\begin{tabular}{|c|c|c|c|c|c|c|}
\hline \multirow[t]{2}{*}{ Client satisfaction issues } & \multirow[t]{2}{*}{ Company size } & \multirow[t]{2}{*}{$\mathbf{N}$} & \multicolumn{4}{|c|}{ Frequencies (\%) } \\
\hline & & & $\begin{array}{l}\text { Very } \\
\text { poor }\end{array}$ & Poor & Fair & Good \\
\hline \multirow[t]{4}{*}{ Professionalism of employers' organisation staff } & Micro & 55 & 3,6 & 1,8 & 63,6 & 30,9 \\
\hline & Small \& med & 44 & 2,3 & 6,8 & 70,5 & 20,5 \\
\hline & Large & 22 & 0,0 & 9,1 & 77,3 & 13,6 \\
\hline & Total & 121 & 2,5 & 4,9 & 68,6 & 23,9 \\
\hline \multirow[t]{4}{*}{ Reliability of information } & Micro & 52 & 1,9 & 3,6 & 50,0 & 44,2 \\
\hline & Small \& med & 44 & 0,0 & 4,6 & 54,6 & 40,9 \\
\hline & Large & 22 & 0,0 & 4,6 & 81,8 & 13,6 \\
\hline & Total & 118 & 8,5 & 4,2 & 57,6 & 37,3 \\
\hline \multirow[t]{4}{*}{ Reply time } & Micro & 50 & 2,0 & 10,0 & 54,0 & 34,0 \\
\hline & Small \& med & 44 & 4,6 & 9,1 & 55,6 & 31,8 \\
\hline & Large & 21 & 0,0 & 19,1 & 71,4 & 9,5 \\
\hline & Total & 115 & 2,6 & 11,3 & 57,4 & 28,7 \\
\hline \multirow[t]{4}{*}{ Accessibility to staff } & Micro & 49 & 4,1 & 16,3 & 48,9 & 30,6 \\
\hline & Small \& med & 44 & 6,8 & 18,2 & 38,6 & 36,4 \\
\hline & Large & 22 & 0,0 & 18,2 & 50,0 & 31,8 \\
\hline & Total & 115 & 4,4 & 17,4 & 45,2 & 33,0 \\
\hline \multirow[t]{4}{*}{ Accessibility to information } & Micro & 51 & 1,9 & 9,8 & 45,1 & 43,1 \\
\hline & Small \& med & 44 & 4,6 & 13,6 & 47,7 & 34,1 \\
\hline & Large & 21 & 0,0 & 14,3 & 52,4 & 33,3 \\
\hline & Total & 116 & 2,6 & 12,1 & 47,4 & 37,9 \\
\hline \multirow{4}{*}{$\begin{array}{l}\text { Relationship between company and employers' } \\
\text { organisation }\end{array}$} & Micro & 54 & 3,7 & 11,1 & 46,3 & 38,9 \\
\hline & Small \& med & 44 & 2,3 & 13,6 & 40,9 & 43,2 \\
\hline & Large & 21 & 0,0 & 4,7 & 47,6 & 47,6 \\
\hline & Total & 119 & 2,5 & 10,9 & 44,5 & 42,0 \\
\hline \multirow{4}{*}{$\begin{array}{l}\text { Overall effectiveness/efficiency of its employers’ } \\
\text { organisation }\end{array}$} & Micro & 54 & 5,6 & 3,7 & 62,9 & 27,8 \\
\hline & Small \& med & 44 & 6,8 & 13,6 & 56,8 & 22,7 \\
\hline & Large & 22 & 0,0 & 9,1 & 72,7 & 18,2 \\
\hline & Total & 120 & 5,0 & 8,3 & 62,5 & 24,2 \\
\hline
\end{tabular}

\footnotetext{
*Missing values excluded
}

Key to Table:

High client satisfaction. 
